Sri Lanka J. Aquat. Sci. 22(1) (2017): 55-66

\title{
Multi-mesh gillnet selectivity of Oreochromis mossambicus and O. niloticus (Cichlidae) in the fishery of three large perennial reservoirs in Sri Lanka
}

\author{
R.P. Prabath K. Jayasinghe ${ }^{1 \dagger}$, Upali S. Amarasinghe ${ }^{1 *}$ and Jacques Moreau ${ }^{2}$ \\ ${ }^{1}$ Department of Zoology and Environmental Management, University of Kelaniya, \\ Kelaniya 11600, Sri Lanka \\ ${ }^{2}$ Ecole Nationale Supérieure Agronomique de Toulouse (ENSAT), P.O. Box 107 Auzeville \\ Tolosane, 31326 Castanet Tolosan Cédex, France \\ *Corresponding author (zoousa@kln.ac.lk)
}

†Present address: Marine Biological Resources Division, National Aquatic Resources Research and Development Agency, Crow Island, Colombo 15, Sri Lanka

Running title: Multi-mesh gillnet selectivity of cichlids

\begin{abstract}
As in many tropical reservoir fisheries, the major fishing gear in the reservoirs of Sri Lanka is gillnet. Gillnets of a wide range of stretched mesh sizes $(6.9-11.4 \mathrm{~cm})$ are used in individual boats in Sri Lankan reservoirs targeting mainly two exotic cichlid species, Oreochromis mossambicus and O. niloticus, which dominate the fisheries accounting for over $80 \%$ of the landings. Although the filament characteristics and dimensions of gillnets of different mesh sizes are uniform, their mesh composition varies from boat to boat making catch samples in individual boats are under the influence of different selectivity patterns. As such, an approach is presented for constructing the overall selection curves in the sampled boats during different sampling occasions for the two cichlid fish species in the three reservoirs. For this purpose, gillnet selectivity of each mesh size was determined using Baranov-Holt method. Probabilities of capture of meshwise gillnet selection curves were then summed up giving weight to the contribution of each mesh size to the total number of net pieces in the sampled boat, to determine the overall gillnet selection from gillnets of all mesh sizes. The importance of the findings of the present study for length-based stock assessment methods and for imposing mesh regulations to the gillnet fisheries in reservoirs of Sri Lanka is discussed.
\end{abstract}

Keywords: artisanal fisheries; Cichlidae; fish stock assessment; mesh regulations; tropical reservoirs

\section{INTRODUCTION}

Tropical lowland reservoirs support profitable fisheries and are affordable sources of animal protein for rural communities in developing countries (Fernando and Holčik 1991; Welcomme 2001; Amarasinghe and De Silva 2015). However, the fishery potential in tropical reservoirs is not fully realized due to the inadequacy of strategies for scientific management (De Silva et al. 1991; De Silva 1996; Welcomme and Bartley 1998; Amarasinghe and De Silva 2015). In many reservoir fisheries in the tropics, major fishing gear is gillnet due their simplicity of construction and operation as well as presence of obstacles for operating any other active fishing gear such as rocks and submerged tree stumps (Welcomme 2001).

It is known that in gillnets, technical characteristics related to net construction such as hanging ratio (Sparre and Venema 1998), filament characteristics such as twine thickness and colour etc. (Hamley 1975; Tweedle and Bodington 1988) and biological characteristics of fish which influence encountering probabilities (Rudstam et al. 1984) have a significant influence of the catch size 
distribution. Even when filament characteristics and dimensions of gillnets used by fishers in individual boats are more or less similar, as is the case of the reservoir fishery of Sri Lanka, selectivity patterns may vary from season to season depending on the use of various mesh gillnets. Correction of length frequencies using a mean selection curve is therefore not adequate to investigate the status of the fisheries of commercially exploited species by multi-mesh gillnets using length-based stock assessment methodologies. Moreover, when the lengthbased stock assessment methodologies (Sparre and Venema 1998; Gayanilo et al. 2005) are employed in such multi-mesh gillnet fisheries, simply pooling of length data of gillnet catches of a fleet of mesh sizes assuming that selectivity effects may be negligible, may introduce bias into growth and mortality estimates.

The Sri Lankan reservoir fishery is almost entirely dependent on exotic cichlid species, Oreochromis mossambicus and $O$. niloticus, which form over $80 \%$ of total landings (Amarasinghe 1998; Schiemer et al. 2001; Amarasinghe and Weerakoon 2009). The major gear in the reservoir fishery of Sri Lanka is gillnet. The fishers however, carry in their boats gillnets of different mesh sizes ranging from $6.9 \mathrm{~cm}$ to $11.4 \mathrm{~cm}$ depending on the availability of desired species and size classes. In the present study, an attempt is made to present an approach for adjusting length frequency data of gillnet catches using overall selection curves of sampled boats with a view to estimating growth parameters of commercially important species in multi-mesh gillnet fisheries in reservoirs of Sri Lanka.

\section{MATERIALS AND METHODS}

Studies were carried out in three Sri Lankan reservoirs (Fig. 1) namely Minneriya ( $8^{\circ} 02^{\prime} \mathrm{N}$; $\left.80^{\circ} 53^{\prime} \mathrm{E}\right)$, Udawalawe $\left(6^{\circ} 27^{\prime} \mathrm{N}\right.$; $\left.80^{\circ} 50^{\prime} \mathrm{E}\right)$ and Victoria ( $7^{\circ} 13^{\prime} \mathrm{N} ; 80^{\circ} 47^{\prime}$ E) from August 1998 to July 2000 . The main fishing craft is nonmotorized, fibre-glass out-rigger canoe and the gear is almost exclusively gillnet although beach seining (illegal) and hook-and-line fishing are carried out sporadically in Minneriya and Udawalawe respectively. In all three reservoirs, fishers used fleets of gillnets of mesh sizes ranging from 6.9 to $11.4 \mathrm{~cm}$ having a hanging ratio of 0.5 .

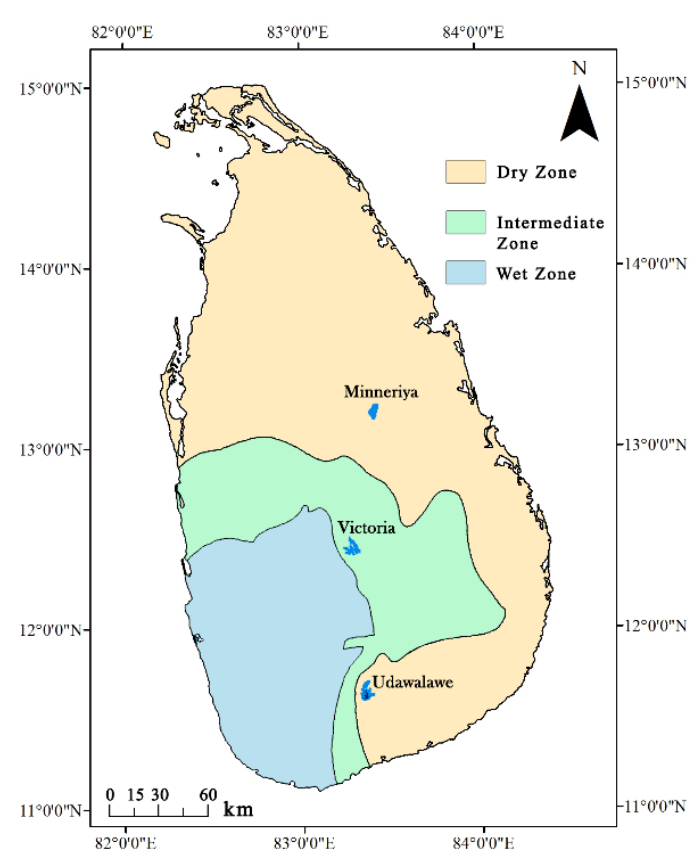

Fig. 1 Map of Sri Lanka showing locations of the three reservoirs investigated (Minneriya; Udawalawe; Victoria). The climatic boundaries between wet zone (south-western part receiving over $250 \mathrm{~cm}$ annual rainfall), intermediate zone $(175-250 \mathrm{~cm}$ annual rainfall) and dry zone $(<175 \mathrm{~cm}$ annual rainfall where most reservoirs are located) are also shown here.

Length frequency data of the two economically important cichlid species i.e., Oreochromis mossambicus and O. niloticus were collected approximately once in two months from the commercial gillnet catches of randomly selected boats in the three reservoirs during the study period. Mesh compositions of gillnets in these sampling boats were also recorded. Mesh-wise length frequency data of these fish species were also collected whenever possible, especially when the fishes were not dislodged from gillnets until the boats arrived at landing sites. Total lengths of fish were measured to nearest $0.5 \mathrm{~cm}$ below the actual length. In the boats from which mesh-wise length frequency data were collected, total weight of each species landed in individual boats, sample weights of the two species separately and number of net pieces (gillnets) of

Sri Lanka J. Aquat. Sci. 22(1) (2017): 55-66 


\section{R.P.P.K. Jayasinghe et al.}

various mesh sizes used in each boat sampled for collection of length frequency data of two cichlid species were also recorded. In addition, lengths and heights of spread of net pieces of each mesh size was determined and the area of a net piece (i.e., spread of the net after laying) of a given mesh size (A) was determined using the following equation.

$$
\mathrm{A}=\left(\mathrm{L}^{*} \mathrm{HR}\right) \mathrm{x}\left(\mathrm{H}^{*} \mathrm{HR}\right)
$$

where, $L=$ stretched length of net piece in $\mathrm{m} ; \mathrm{H}$ = stretched height of net piece in $\mathrm{m}$; and $\mathrm{HR}=$ hanging ratio (i.e., ratio of hung length to stretched length of net; Hamley 1975). In Sri Lankan reservoir fisheries, HR of gillnet is generally 0.5 .

Gillnet selection patterns of individual mesh sizes were determined by Baranov-Holt method (Baranov 1914; Holt 1963; Hamley 1975). In order to meet the assumption in this method that fishing mortalities exerted by two adjacent mesh sizes are the same, length frequency data in the two mesh sizes were adjusted for a constant fishing effort (i.e., number of fish per $1000 \mathrm{~m}^{2}$ area of net per day) as follows:

$$
f_{\text {adj }}=\left[\left(f_{\text {obs }} W\right) /(w A n)\right] \times 1000
$$

where $\mathrm{f}_{\mathrm{adj}}=$ adjusted frequency (i.e., number of fish per $1000 \mathrm{~m}^{2}$ area of net per day); $\mathrm{f}_{\mathrm{obs}}=$ number of fish caught in a given mesh size; $\mathrm{W}$ $=$ total weight of fish landed by gillnets observed; $\mathrm{w}=$ sample weight of fish; $\mathrm{A}=$ area (in $\mathrm{m}^{2}$ ) of a gillnet piece; $\mathrm{n}=$ number of net pieces observed.

The logarithms of ratios of $f_{\text {adj }}$ in overlapping ranges of two adjacent mesh sizes were related to mid-point of length class (L), which were of the following form (Hamley 1975).

$$
\operatorname{Ln} \mathrm{C}_{2} / \mathrm{C}_{1}=\mathrm{a}+\mathrm{bL}
$$

where $C_{1}$ and $C_{2}$ are $f_{\text {adj }}$ in a length class in mesh sizes, $\mathrm{M}_{1}$ and $\mathrm{M}_{2}$ respectively and $\mathrm{a}$ and $\mathrm{b}$ are constants. The intercept (a) and the slope (b) of the equation 2 were used to determine optimal length for mesh size $\mathrm{M}_{1}\left(\mathrm{~L}_{\mathrm{opt}(1)}\right)$ and $\mathrm{M}_{2}\left(\mathrm{~L}_{\mathrm{opt}(2)}\right)$ as follows:

$$
\begin{aligned}
& \left(\mathrm{L}_{\text {opt }(1)}\right)=-2 \mathrm{a}\left(\mathrm{M}_{1}\right) / \mathrm{b}\left(\mathrm{M}_{1}+\mathrm{M}_{2}\right) \\
& \left(\mathrm{L}_{\mathrm{opt}(2)}\right)=-2 \mathrm{a}\left(\mathrm{M}_{2}\right) / \mathrm{b}\left(\mathrm{M}_{1}+\mathrm{M}_{2}\right)
\end{aligned}
$$

The standard deviation (SD) of both selection curves were estimated by;

$$
\mathrm{SD}=\left\{2 \mathrm{a}\left(\mathrm{M}_{1}-\mathrm{M}_{2}\right) /\left[\mathrm{b}^{2}\left(\mathrm{M}_{1}+\mathrm{M}_{2}\right)\right]\right\}^{0.5}
$$

When there are two estimates of SD for a particular species in a given mesh size, mean value was taken. Using $\mathrm{L}_{\mathrm{opt}(1)}, \mathrm{L}_{\mathrm{opt}(2)}$ and $\mathrm{SD}$ values, probabilities of capture of length $\mathrm{L}$, in each mesh size $\left(\mathrm{P}_{1}\right.$ and $\left.\mathrm{P}_{2}\right)$ were estimated by the following equations.

For mesh size $\mathrm{M}_{1}$ :

$$
\begin{gathered}
\mathrm{P}_{1}=\left[-\left(\mathrm{L}-\mathrm{L}_{\mathrm{opt}(1)}\right)^{2} / 2 \mathrm{SD}^{2}\right] \\
\text { For mesh size } \mathrm{M}_{2}: \\
\mathrm{P}_{2}=\left[-\left(\mathrm{L}-\mathrm{L}_{\mathrm{opt}(2)}\right)^{2} / 2 \mathrm{SD}^{2}\right]
\end{gathered}
$$

Selection factor (SF) for each species for each mesh size was estimated as,

$$
\mathrm{SF}=\mathrm{L}_{\mathrm{opt}} / \text { mesh size (Hamley 1975) (7) }
$$

The overall probability of capture $\left(\mathrm{P}_{\mathrm{t}}\right)$ of all gillnets in the $\mathrm{j}^{\text {th }}$ length class of fish in the multimesh gillnet fishery in the sampled boat, from which mesh-wise length frequency data could not be collected, was estimated as,

$$
\mathrm{P}_{\mathrm{t}}=\left(\sum\left(\mathrm{n}_{\mathrm{i}} \mathrm{P}_{\mathrm{ij}}\right)\right) / \max \left(\sum\left(\mathrm{n}_{\mathrm{i}} \mathrm{P}_{\mathrm{ij}}\right)\right)
$$

where, $n_{i}=$ number of net pieces of $i^{\text {th }}$ mesh gillnet; $\mathrm{P}_{\mathrm{ij}}=$ probability of capture in $\mathrm{i}^{\text {th }}$ mesh gillnet in $\mathrm{j}^{\text {th }}$ length class; and $\max \left(\sum\left(\mathrm{n}_{\mathrm{i}} \mathrm{P}_{\mathrm{ij}}\right)\right)=$ maximum value of $\left(\sum\left(n_{\mathrm{i}} \mathrm{P}_{\mathrm{ij}}\right)\right)$ estimated. Using this equation, the gillnet selection curves and number of net pieces of different mesh sizes carried in the sampled boats were used to estimate overall selection curves for landed boats in each sampling occasion.

\section{RESULTS}

Number of net pieces and areas of gillnets of each mesh size in the sampled boats, total weight of fish of each species caught in gillnets of individual mesh sizes and their sample weights are given in Table 1. Here sample weights were estimated using the method described by Bayer (1987) using length-weight relationships of individual species (Table 1). Number of fish measured for determining mesh-wise length frequency data ranged from 103 in mesh size $11.4 \mathrm{~cm}$ in Udawalawe to 672 in $10.2 \mathrm{~cm}$ mesh size in Minneriya for $O$. mossambicus and from 103 in $11.4 \mathrm{~cm}$ mesh size in Udawalawe to 491 in $8.4 \mathrm{~cm}$ mesh size in Udawalawe for $O$. niloticus (Table 1). Mean number of gillnet pieces $( \pm \mathrm{SE})$ of different mesh sizes used in the sampling boats during the study period is shown in Figure 2 for the three reservoirs separately. They indicate that there is broad variation in mesh composition of

Sri Lanka J. Aquat. Sci. 22(1) (2017): 55-66 
Table 1 Number of net pieces and areas of gillnets of each mesh size in the sampled boats, total weight of $O$. mossambicus and $O$. niloticus caught in gillnets of individual mesh sizes and their sample weights. Also given here are number of fish measured for determining mesh-wise length frequency data, and length-weight relationship of each species in each reservoir. $\mathrm{L}=$ Total length in $\mathrm{cm} ; \mathrm{W}=$ Body weight in $\mathrm{g}$.

\begin{tabular}{|c|c|c|c|c|c|c|}
\hline $\begin{array}{l}\text { Reservoir/Species } \\
\text { /Length-weight } \\
\text { relationship }\end{array}$ & $\begin{array}{r}\text { Mesh size } \\
(\mathrm{cm})\end{array}$ & $\begin{array}{r}\text { Number of } \\
\text { net pieces } \\
\text { observed }\end{array}$ & $\begin{array}{r}\text { Area of } \\
\text { net piece } \\
\left(\mathrm{m}^{2}\right)\end{array}$ & $\begin{array}{r}\text { Total } \\
\text { weight } \\
\text { landed } \\
(\mathrm{kg})\end{array}$ & $\begin{array}{r}\text { Sample } \\
\text { weight } \\
(\mathrm{kg})\end{array}$ & $\begin{array}{l}\text { No. of fish } \\
\text { measured }\end{array}$ \\
\hline \multicolumn{7}{|l|}{ Minneriya } \\
\hline O. mossambicus & 6.9 & 34 & 223.17 & 24.0 & 11.53 & 118 \\
\hline \multirow[t]{3}{*}{$\mathrm{W}=0.0152 \mathrm{~L}^{3.0445}$} & 7.6 & 29 & 173.28 & 30.0 & 21.98 & 192 \\
\hline & 8.9 & 32 & 237.63 & 62.0 & 43.57 & 297 \\
\hline & 10.2 & 61 & 234.09 & 158.0 & 144.06 & 672 \\
\hline O. niloticus & 6.9 & 34 & 223.17 & 77.5 & 22.78 & 306 \\
\hline \multirow[t]{3}{*}{$\mathrm{W}=0.0270 \mathrm{~L}^{2.7860}$} & 7.6 & 36 & 173.28 & 106.0 & 36.01 & 395 \\
\hline & 8.9 & 80 & 237.63 & 87.6 & 57.60 & 485 \\
\hline & 10.2 & 28 & 234.09 & 70.0 & 58.15 & 362 \\
\hline \multicolumn{7}{|l|}{ Udawalawe } \\
\hline O. mossambicus & 8.4 & 65 & 211.68 & 36.5 & 14.00 & 204 \\
\hline \multirow[t]{2}{*}{$\mathrm{W}=0.0138 \mathrm{~L}^{2.8930}$} & 10.2 & 55 & 234.09 & 49.9 & 19.30 & 168 \\
\hline & 11.4 & 24 & 146.21 & 21.0 & 14.32 & 103 \\
\hline O. niloticus & 8.4 & 65 & 211.68 & 196.0 & 34.13 & 491 \\
\hline \multirow[t]{2}{*}{$\mathrm{W}=0.1430 \mathrm{~L}^{2.9300}$} & 10.2 & 26 & 234.09 & 62.5 & 29.66 & 146 \\
\hline & 11.4 & 20 & 146.21 & 33.0 & 23.87 & 103 \\
\hline \multicolumn{7}{|l|}{ Victoria } \\
\hline O. mossambicus & 6.9 & 67 & 223.17 & 34.7 & 23.88 & 260 \\
\hline \multirow[t]{5}{*}{$\mathrm{W}=0.0179 \mathrm{~L}^{2.9988}$} & 7.6 & 49 & 173.28 & 56.9 & 26.78 & 241 \\
\hline & 8.4 & 31 & 211.68 & 63.3 & 46.41 & 410 \\
\hline & 8.9 & 69 & 237.63 & 35.6 & 22.82 & 141 \\
\hline & 10.2 & 60 & 234.09 & 28.8 & 22.54 & 111 \\
\hline & 11.4 & 14 & 146.20 & 67.0 & 55.53 & 204 \\
\hline O. niloticus & 6.9 & 31 & 223.17 & 24.5 & 11.80 & 113 \\
\hline \multirow[t]{5}{*}{$\mathrm{W}=0.0940 \mathrm{~L}^{2.2026}$} & 7.6 & 37 & 173.28 & 24.5 & 13.96 & 116 \\
\hline & 8.4 & 40 & 211.68 & 28.1 & 18.32 & 137 \\
\hline & 8.9 & 83 & 237.63 & 100.5 & 62.82 & 416 \\
\hline & 10.2 & 50 & 234.09 & 63.0 & 55.67 & 194 \\
\hline & 11.4 & 106 & 146.20 & 158.0 & 107.76 & 210 \\
\hline
\end{tabular}

the gillnet panels used in the boats sampled justifying that the length frequency data collected in a particular occasion are needed to be corrected for overall selectivity in the sampled boats.

Relationships of Ln Catch ratios of adjusted length frequencies $\left(f_{\text {adj }}\right)$ of each species in the overlapping ranges of two adjacent mesh sizes $\left(\operatorname{Ln} \mathrm{C}_{2} / \mathrm{C}_{1}\right)$ to mid-points of length classes (L) are given in Table 2. Regression relationships between $\mathrm{Ln} \mathrm{C}_{2} / \mathrm{C}_{1}$ and $\mathrm{L}$ for individual species in three mesh combinations for $O$. mossambicus and $O$. niloticus in Minneriya reservoirs are shown in Fig. 3 as a representative example. As all regression relationships are significant at least at 0.05 probability level (Table 2), the normal spread model is appropriate for the gillnet selection for all mesh sizes for both cichlid species in the three reservoirs. 


\section{R.P.P.K. Jayasinghe et al.}

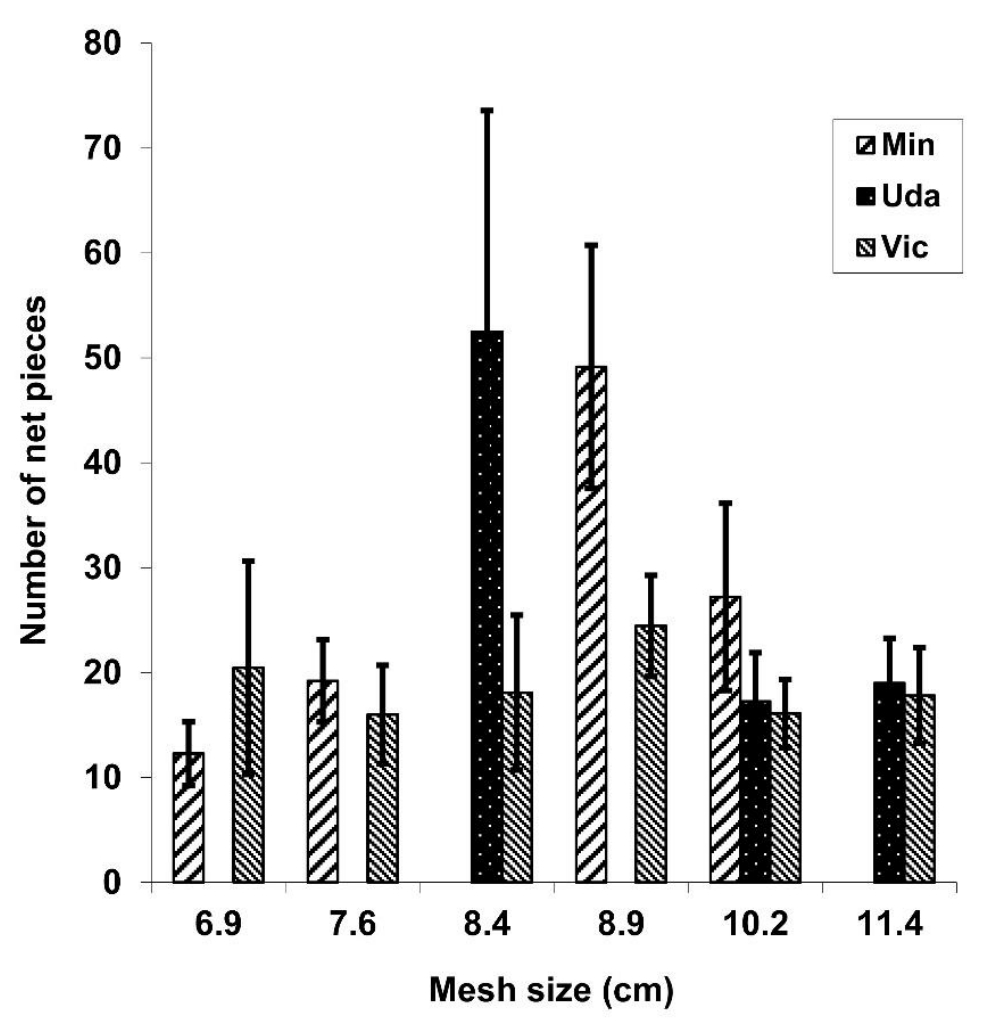

Fig. 2 Mean number of net pieces $( \pm S E$ of mean) in each mesh size in the sampled boats in Minneriya (Min), Udawalawe (Uda) and Victoria (Vic) reservoirs of Sri Lanka.
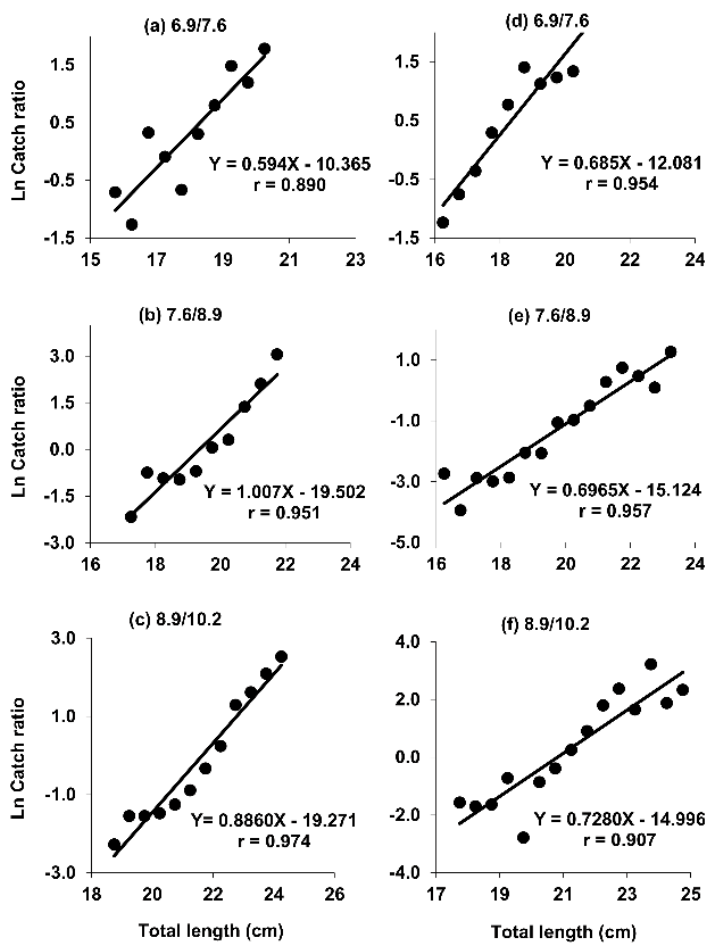

Fig. 3 Representative regression relationships between Ln Catch ratio and Total length $(\mathrm{cm})$ for $O$. mossambicus (a to c) and O. niloticus (d to $f$ ) in Minneriya reservoir. The three mesh combinations used for the analysis are also indicated here. All relationships are significant at least at 0.001 probability level. 
60

$$
\text { R.P.P.K. Jayasinghe et al. }
$$

Table 2 Relationships of Ln Catch ratios of adjusted length frequencies ( $\left.f_{\text {adj }}\right)$ of each species in the overlapping ranges of two adjacent mesh sizes $\left(\operatorname{Ln~} C_{2} / C_{1}\right)$ to mid-points of length classes $(\mathrm{L})$. $\mathrm{r}=$ Correlation coefficient. All relationships are significant at least at 0.001 probability level.

\begin{tabular}{|c|c|c|c|}
\hline $\begin{array}{l}\text { Reservoir/Species/Mesh } \\
\text { combination }(\mathrm{cm})\end{array}$ & $\begin{array}{l}\text { Relationship ( } \mathrm{Y}=\mathrm{Ln}_{2} / \mathrm{C}_{1} ; \mathrm{X}=\mathrm{L} \\
\text { in } \mathrm{cm} \text { ) }\end{array}$ & $\begin{array}{l}\text { Size range used } \\
(\mathrm{cm})\end{array}$ & $\mathrm{r}$ \\
\hline \multicolumn{4}{|c|}{ Minneriya/ O. mossambicus } \\
\hline $6.9 / 7.6$ & $Y=0.5937 X-10.365$ & $15.75-20.25$ & 0.890 \\
\hline $7.6 / 8.9$ & $Y=1.0073 X-19.502$ & $17.25-21.75$ & 0.951 \\
\hline $8.9 / 10.2$ & $Y=0.8860 X-19.271$ & $18.75-24.25$ & 0.974 \\
\hline \multicolumn{4}{|l|}{ O. niloticus } \\
\hline $6.9 / 7.6$ & $Y=0.6854 X-12.081$ & $16.25-20.75$ & 0.954 \\
\hline $7.6 / 8.9$ & $Y=0.6965 X-15.124$ & $16.25-23.25$ & 0.957 \\
\hline $8.9 / 10.2$ & $Y=0.7280 X-14.996$ & $17.75-24.75$ & 0.907 \\
\hline \multicolumn{4}{|c|}{ Udawalawe/ O. mossambicus } \\
\hline $8.4 / 10.2$ & $Y=0.8178 X-17.235$ & $18.75-24.75$ & 0.913 \\
\hline $10.2 / 11.4$ & $Y=0.4252 X-10.175$ & $22.75-27.25$ & 0.901 \\
\hline \multicolumn{4}{|l|}{ O. niloticus } \\
\hline $8.4 / 10.2$ & $Y=1.0697 X-24.696$ & $20.25-25.75$ & 0.883 \\
\hline $10.2 / 11.4$ & $Y=0.9412 X-25.541$ & $25.25-29.25$ & 0.904 \\
\hline \multicolumn{4}{|l|}{ Victoria/ O. mossambicus } \\
\hline $6.9 / 7.6$ & $Y=1.1069 X-18.902$ & $16.25-19.25$ & 0.981 \\
\hline $7.6 / 8.4$ & $Y=0.2878 X-4.8968$ & $16.25-19.25$ & 0.800 \\
\hline $8.9 / 10.2$ & $\mathrm{Y}=0.4841 \mathrm{X}-10.937$ & $19.25-25.25$ & 0.783 \\
\hline $10.2 / 11.4$ & $Y=1.6733 X-37.545$ & $22.25-25.75$ & 0.948 \\
\hline \multicolumn{4}{|l|}{ O. niloticus } \\
\hline $6.9 / 7.6$ & $Y=0.8058 X-13.722$ & $16.75-19.75$ & 0.849 \\
\hline $7.6 / 8.4$ & $Y=0.4654 X-10.841$ & $17.25-22.25$ & 0.751 \\
\hline $8.9 / 10.2$ & $Y=0.6660 X-15.339$ & $19.75-26.75$ & 0.866 \\
\hline $10.2 / 11.4$ & $Y=0.5363 X-14.120$ & $22.75-29.75$ & 0.886 \\
\hline
\end{tabular}


R.P.P.K. Jayasinghe et al.

Table 3 Estimated optimal lengths, selection factors, standard deviation of selection curves and corresponding selection ranges of $O$. mossambicus and $O$. niloticus for each mesh size of gillnets in the three reservoirs.

\begin{tabular}{|c|c|c|c|c|}
\hline $\begin{array}{l}\text { Reservoir/Fish } \\
\text { species/Mesh } \\
\text { size }(\mathrm{cm})\end{array}$ & $\begin{array}{l}\text { Optimal length } \\
(\mathrm{cm})\end{array}$ & Selection factor & $\begin{array}{l}\text { Standard } \\
\text { deviation }\end{array}$ & $\begin{array}{l}\text { Selection } \\
\text { range }(\mathrm{cm})\end{array}$ \\
\hline \multicolumn{5}{|l|}{ Minneriya } \\
\hline \multicolumn{5}{|l|}{ O. mossambicus } \\
\hline 6.9 & 16.61 & 2.40 & 1.68 & $14.48-18.29$ \\
\hline 7.6 & 18.06 & 2.37 & 1.71 & $16.35-19.77$ \\
\hline 8.9 & 20.57 & 2.33 & 1.78 & $18.79-22.35$ \\
\hline 10.2 & 23.23 & 2.27 & 1.82 & $21.41-25.05$ \\
\hline \multicolumn{5}{|l|}{ O. niloticus } \\
\hline 6.9 & 16.77 & 2.43 & 1.57 & $15.20-18.34$ \\
\hline 7.6 & 19.23 & 2.53 & 1.70 & $17.53-20.93$ \\
\hline 8.9 & 21.30 & 2.39 & 1.90 & $19.40-23.20$ \\
\hline 10.2 & 22.00 & 2.15 & 1.96 & 20.04-23.96 \\
\hline \multicolumn{5}{|l|}{ Udawalawe } \\
\hline \multicolumn{5}{|l|}{ O. mossambicus } \\
\hline 8.4 & 19.03 & 2.26 & 2.23 & $16.80-21.26$ \\
\hline 10.2 & 22.91 & 2.24 & 2.36 & $20.55-25.27$ \\
\hline 11.4 & 25.25 & 2.21 & 2.50 & $22.75-27.75$ \\
\hline \multicolumn{5}{|l|}{ O. niloticus } \\
\hline 8.4 & 20.85 & 2.48 & 2.04 & $18.81-22.89$ \\
\hline 10.2 & 25.25 & 2.47 & 1.91 & $23.34-27.61$ \\
\hline 11.4 & 28.64 & 2.51 & 1.78 & $26.86-30.42$ \\
\hline \multicolumn{5}{|l|}{ Victoria } \\
\hline \multicolumn{5}{|l|}{ O. mossambicus } \\
\hline 6.9 & 16.25 & 2.35 & 1.22 & $15.03-17.47$ \\
\hline 7.6 & 17.26 & 2.27 & 1.82 & $15.44-19.08$ \\
\hline 8.4 & 17.86 & 2.12 & 2.4 & $15.43-20.29$ \\
\hline 8.9 & 21.05 & 2.36 & 2.52 & $18.53-23.57$ \\
\hline 10.2 & 22.66 & 2.22 & 1.87 & $20.79-24.53$ \\
\hline 11.4 & 23.86 & 2.09 & 1.22 & $22.64-25.05$ \\
\hline \multicolumn{5}{|l|}{ O. niloticus } \\
\hline 6.9 & 16.20 & 2.34 & 1.44 & $14.76-17.64$ \\
\hline 7.6 & 18.06 & 2.37 & 1.83 & $16.23-19.89$ \\
\hline 8.4 & 20.19 & 2.40 & 2.23 & $17.96-22.42$ \\
\hline 8.9 & 21.45 & 2.41 & 2.16 & $19.29-23.61$ \\
\hline 10.2 & 24.79 & 2.43 & 2.24 & $22.55-27.03$ \\
\hline 11.4 & 27.94 & 2.45 & 2.33 & $25.61-30.27$ \\
\hline
\end{tabular}

Sri Lanka J. Aquat. Sci. 22(1) (2017): 55-66 

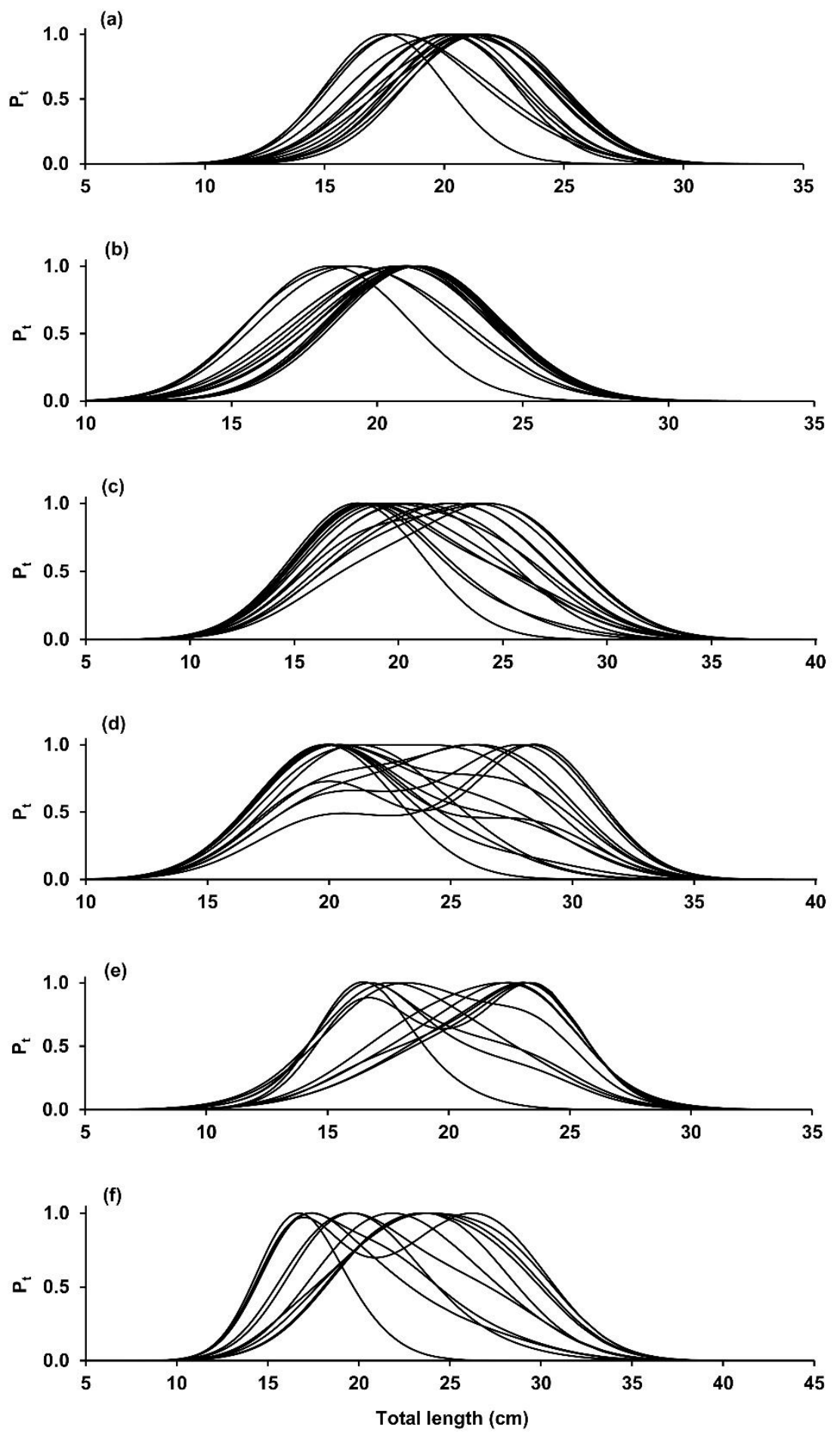

Fig. 4 The estimated overall gillnet selection curves for the sampled boats in each sampling occasion for the two cichlid fish species in the three reservoirs. Vertical axis - Probabilities of capture $\left(\mathrm{P}_{\mathrm{i}}\right)$; Horizontal axis - Total length (cm). (a) O. mossambicus in Minneriya; (b) O. niloticus in Minneriya; (c) O. mossambicus in Udawalawe; (d) O. niloticus in Udawalawe; (e) $O$. mossambicus in Victoria; (f) $O$. niloticus in Victoria. 
The estimated optimal lengths, selection factors, standard deviations of selection curves and corresponding selection ranges of the two cichlid species for each mesh size of gillnets in the three reservoirs are given in Table 3. The estimated overall gillnet selection curves for the sampled boats in each sampling occasion for the two cichlid fish species in the three reservoirs are shown in Fig. 4. They indicate that the overall selection curves in the sampled boats during different sampling occasions vary from each other.

The optimal lengths in the gillnet selection curves of $O$. mossambicus and $O$. niloticus in the three reservoirs were significantly related to mesh size $(p<0.001$; Fig. $5)$. The relationships of selection range to the mesh size in both $O$. mossambicus and $O$. niloticus (Fig. 6) are positive second order parabolic, which perhaps indicate that larger $(>8.9 \mathrm{~cm})$ mesh gillnets are effective for catching narrow size ranges of fish probably due to the shift of size composition of the fish stocks towards dominance of smaller individuals.
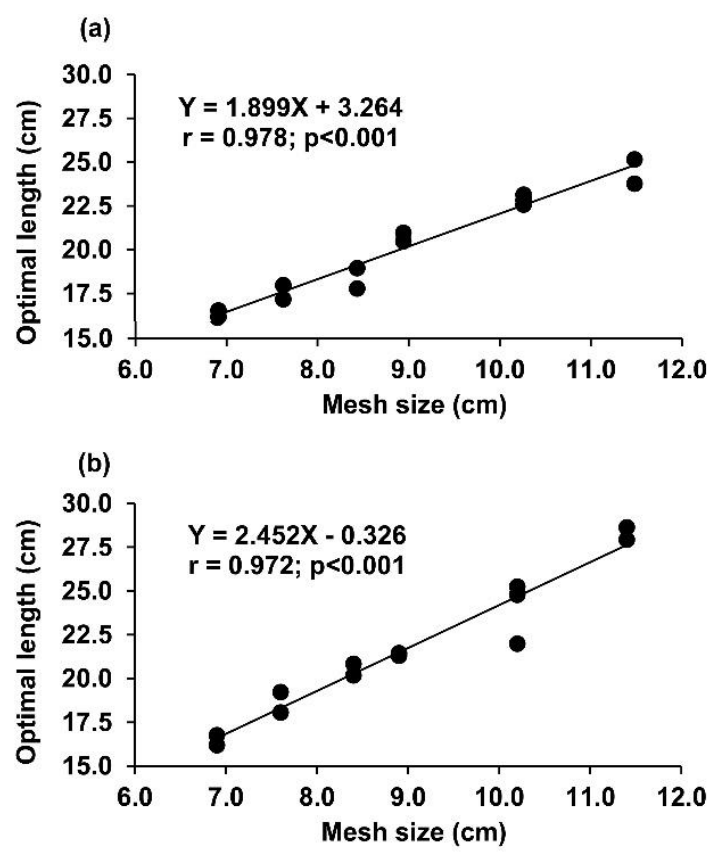

Fig. 5 Relationships of optimal length to mesh size for (a) O. mossambicus and (b) O. niloticus in three reservoirs.
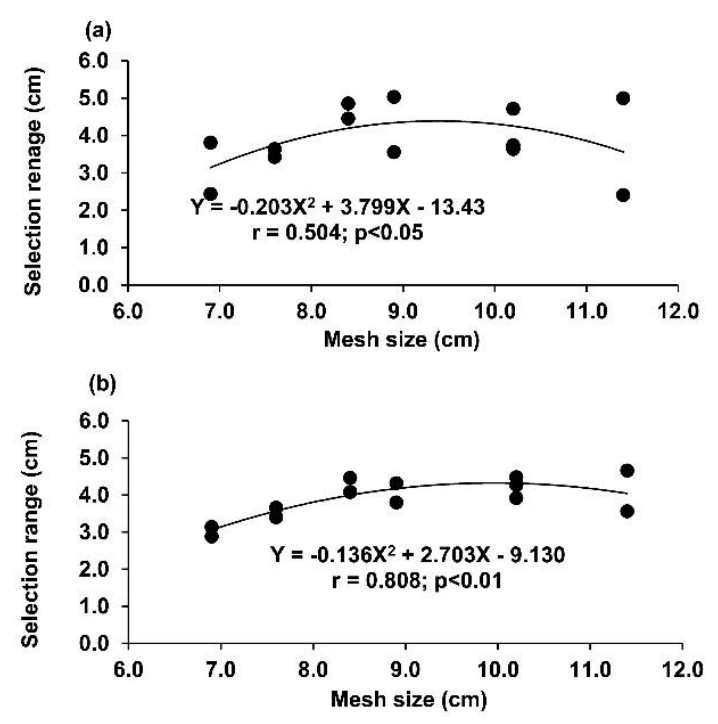

Fig. 6 Relationship between selection range and gillnet mesh size for (a) O. mossambicus and (b) $O$. niloticus in the three reservoirs.

\section{DISCUSSION}

Although gillnet is known to be an effective sampling device for freshwater fish (Craig et al., 1986), gillnet catch efficiencies are known to be influenced by hanging ratio, colour, fishing height, twine diameter and material (Gray et al. 2005). Due to the gillnet selectivity effect, a specific mesh size is often most effective for a narrow range of length of fish. Fish morphology such as presence of spines also influences probabilities of capture in gillnets. Furthermore, gillnets are not readily operable anywhere in lakes and reservoirs so that restriction of gillnet operations to certain habitats also influences gear selectivity. As such, it is imperative that length-based stock assessment procedures be applied to gillnet catches with appropriate corrections for gillnet selectivity. As in many artisanal fisheries, collection of length frequency data from gillnets of each mesh size separately is often impossible in Sri Lankan reservoirs because most fishermen do not land mesh-wise gillnet catches of fish separately. This makes it difficult to correct length frequency data for gillnet selection. Prchalová et al. (2009) also have highlighted the importance of an accurate method for correction of selectivity of multi-meshed gillnet fisheries

Sri Lanka J. Aquat. Sci. 22(1) (2017): 55-66 
for fish size distributions in order to prevent misleading interpretation of gillnet sampling. Further, Hansson and Rudstam (1995) presented a methodology for determining a combined selectivity profile for a gang of gillnets with overlapping selectivity curves, which involved summing up of relative selectivity of individual mesh sizes for different size classes of fish. However, such a methodology is not readily applicable for determining the total selectivity function of a gang of gillnets in the reservoir fisheries of Sri Lanka because composition of the mesh sizes of gillnets that fishermen carry in their boats is not consistent but varies depending on various factors such as seasonal abundance of riverine cyprinids during rainy seasons (De Silva 1983) and increased catchability of some macrophyte feeding cichlid species such as Tilapia rendalli in gillnets during the seasons of inundation of peripheral areas of reservoirs (Amarasinghe and Samarakoon 1988). Hence relative contribution of each mesh size to the overall selection should be incorporated in determining the total selectivity function in multi-mesh gillnet fisheries.

As almost all gillnets used in Sri Lankan reservoir fisheries, although prohibited by law, are mono-filament gillnets, filament characteristics such as twine thickness can be expected to have an influence of size selectivity, as shown by Holst et al. (2002). In spite of similar filament characteristics in gillnets of all three reservoirs, the selection ranges of the two cichlid species (Table 3 ) are somewhat different between the three reservoirs and between the mesh sizes within a reservoir. As such, in a gang of gillnets of different mesh sizes, selectivity effects may be assumed to be negligible when length data are simply pooled (Amarasinghe et al. 1989). However, due to the fact that fishers use gillnets of various compositions of mesh sizes, the selectivity effects in catch samples in individual boats are not consistent so that accuracy of estimation of growth parameters from length-based methods can be improved by incorporating overall selection patterns of sampled boats, as shown in the present analysis.

In addition, the relationships between the optimal length and mesh size of gillnets (Fig. 5) provide useful information of imposing mesh regulations of the gillnet fisheries. The narrower selection range in larger $(>8.9 \mathrm{~cm})$ mesh gillnets than those with smaller mesh (< $8.9 \mathrm{~cm}$ ) might imply that the cichlid fish stocks in all three reservoirs are in the wake of moving their size composition towards the dominance of smaller sized individuals. According to Welcomme (2001), this is a general trend in most inland fisheries of the world.

\section{Acknowledgements}

This study was carried out as part of the EUfunded 'FISHSTRAT' project (Project No. IC 18CT 970190). We are grateful to late Dr. Annie Duncan, who coordinated the project until 1999, for her help and encouragement. Thanks are also due to Professor David Simon (Royal Holloway, University of London), who has served as the coordinator of the project after Dr. Annie Duncan's terminal illness in 1999. Mr. P.A.D. Ajith Kumara and Dr. W.S. Weliange assisted in field data collection.

\section{REFERENCES}

Amarasinghe U.S. 1998. Reservoir Fisheries Management in Sri Lanka: Achievements, Mistakes and Lessons for Future. International Review of Hydrobiology 83 (Special Issue): 523530.

Amarasinghe U.S. and S.S. De Silva 2015. Fishes and fisheries of Asian inland lacustrine waters. pp. 384-403. In: Craig, J.F. (Ed.), Freshwater Fisheries Ecology. John Wiley and Sons, Chichester. doi: 10.1002/9781118394380.ch31

Amarasinghe U.S. and J.I. Samarakoon 1988. Some factors affecting contribution of cichlid species, Etroplus suratensis and Tilapia rendalli to gillnet catches in a man-made lake in Sri Lanka. Asian Fisheries Science 2: 17-26.

Amarasinghe U.S. and D.E.M. Weerakoon 2009. Present status and future strategies for the management of reservoir fisheries in Sri Lanka. pp. 6998. In: S.S. De Silva and U.S. Amarasinghe (eds), Status of reservoir

Sri Lanka J. Aquat. Sci. 22(1) (2017): 55-66 
R.P.P.K. Jayasinghe et al.

fisheries in five Asian countries. NACA Monograph No. 2. Network of Aquaculture Centres in Asia-Pacific, Bangkok, Thailand.

Amarasinghe U.S., S.S. De Silva and J. Moreau 1989. Spatial changes in growth and mortality and effects on the fishery of Oreochromis mossambicus (Pisces, Cichlidae) in a man-made lake in Sri Lanka. Asian Fisheries Science 3: 57-68.

Baranov F.I. 1914. The capture fishery of gillnets. Mater Poznaniyu Russ. Rybolov. 3(6): 56-69. In Russian, translated version in 1976, Selected works on fishing gear Vol. I. Commercial fishing techniques. Israel programme for scientific translations, Jerusaleum.

Bayer J.E. 1987. On length-weight relationships Part I Computing the mean weight of the fish in given length class. Fishbyte 5(1): 11-13.

Craig J.F., A. Sharma, K. Smiley 1986. The variability in catches from multi-mesh gillnets fishes in three Canadian lakes. Journal of Fish Biology 28: 671-678. doi:

10.1111/j.1095-8649.1986.tb05202.x

De Silva S.S. 1983. Reproductive strategies of some major fish species in Parakrama Samudra reservoir and their possible impact on the ecosystem- a theoretical consideration. pp. 185-191. In: F. Schiemer (ed.), Limnology of Parakrama Samudra-Sri Lanka: A case study of an ancient man-made lake in the tropics. Developments in Hydrobiology, 12, Dr. W. Junk Publishers, The Hauge, The Netherlands.

De Silva S.S. 1996. The Asian inland fishery with special reference to reservoir fisheries: A reappraisal. pp. 321-332. In: F. Schiemer and K.T. Boland (eds), Perspectives in Tropical Limnology. SPB Academic Publishing, Amsterdam, The Netherlands.

De Silva S.S., J. Moreau, U.S. Amarasinghe, T. Chookajorn and R.D. Guerrero 1991. A comparative assessment of the fisheries in lacustrine inland waters in three Asian countries based on catch and effort data. Fisheries Research 11: 177-189.

Fernando C.H. and J. Holčik 1991. Fish in reservoirs. Internationale Revue der gesamten Hydrobiologie und Hydrographie 76: 149-167. doi: 10.1002/iroh.19910760202

Gayanilo F.C.Jr., P. Sparre and D. Pauly 2005. FAO-ICLARM Stock Assessment Tools II (FiSAT II). Revised version. User's Guide. FAO Computerized Information Series (Fisheries) No.8, Revised version. Penang, World Fish Centre and Rome, FAO. 168 p.

Gray C.A., M.K., Broadhurst, D.D. Johnson and D.J. Young 2005. Influences of hanging ratio, fishing height, twine diameter and material of bottom-set gillnets on catches of dusky flathead Platycephalus fuscus and non-target species in New South Wales, Australia. Fisheries Science 71: 1217-1228. doi: 10.1111/j.1444-2906.2005.01086.x

Hamley J.M. 1975. Review of gillnet selectivity. Journal of the Fisheries Research Board of Canada 32: 19431969. doi: 10.1139/f75-233

Hansson S. and L.G. Rudstam 1995. Gillnet catches as an estimate of fish abundance: a comparison between vertical gillnet catches and hydroacoustic abundance of Baltic Sea herring (Clupea harengus) and spart (Sprattus sprattus). Canadian Journal of Fisheries and Aquatic Sciences 52: 75-83. doi: 10.1139/f95-007

Holst R., D. Wileman and N. Madsen 2002. The effects of twine thickness on the size selectivity and fishing power of Baltic cod gill nets. Fisheries Research 56: 303-312. http://dx.doi:.org/10.1016/S01657836(01)00328-9.

Holt S.J. 1963. A method for determining gear selectivity and its application. International Commission for the North Atlantic Fisheries (ICNAF) Special Publication 5: 106-115.

Prchalová M., J. Kubečka, M. Ř́íha, T. Mrkvička, M. Vašek, T. Jůza, M. Kratochvíl, J. Peterka, V. Draštík nd J. 
Kř́žzek 2009. Size selectivity of standardized multimesh gillnets in sampling coarse European species. Fisheries Research 96: 51-57. doi:10.1016/j.fishres.2008.09.017

Rundstam L.G., J.M. Magnuson and W.L. Tonn 1984. Size selectivity of passive fishing gear: A correction for encounter probability applied to gill nets. Canadian Journal of Fisheries and Aquatic Sciences 41: 1252-1255. doi: 10.1139/f84-151

Schiemer F., U.S. Amarasinghe, J. Frouzova, B. Sricharoendham and E.I.L. Silva 2001. Ecosystem structure and dynamics - a management basis for Asian reservoirs and lakes. pp. 215-226. In: S.S. De Silva (ed.), Reservoir and Culture-based Fisheries: Biology and Management. ACIAR, Canberra, Australia.

Sparre P. And S.C. Venema 1998. Introduction to tropical fish stock assessment. Part 1. Manual. FAO Fisheries Technical Paper No. 306.1, Rev. 2. FAO, Rome. $407 \mathrm{p}$.

Tweedle D. and P. Bodington 1988. A comparison of the effectiveness of black and white gillnets in Lake Malawi, Africa. Fisheries Research 6: 257-269.

doi: 10.1016/0165-7836(88)90018-5

Welcomme R.L. 2001. Inland Fisheries: Conservation and Management. Fishing News Books, Blackwell, Oxford.

Welcomme R.L. and D.M. Bartley 1998. Current approaches to the enhancement of fisheries. Fisheries Management and Ecology 5: 351-382. doi:

10.1046/j.1365-2400.1998.550351.x 